\title{
Kinerja Keuangan Daerah Kabupaten Sukoharjo Ditinjau dari Perspektif Otonomi Daerah
}

\author{
${ }^{1}$ Arnita Febriana Puryatama, ${ }^{2}$ Kristina Setyowati \\ ${ }^{1}$ Universitas Sebelas Maret Surakarta, Indonesia; febriana_660@student.uns.ac.id \\ ${ }^{2}$ Universitas Sebelas Maret Surakarta, Indonesia; kristina@staff.uns.ac.id
}

\begin{abstract}
Regional finance has a pivotal role in regional autonomy because regional finance reflects the ability of regions in running the local government. One of the tools to analyze local government financial performance is ratio analysis. The purpose of this study was to determine how the regional financial performance of Sukoharjo Regency in terms of regional autonomy perspective. This research uses descriptive quantitative method. The data used in this research is secondary in the form of financial report data Sukoharjo regency in 2015-2019 were obtained using the time series technique. The analysis results show that the financial performance of Sukoharjo regency is still not optimal. This is indicated by lack of ability to extract local revenue known from the low of DDF ratio, DOF ratio, Fiscal capacity and fiscal effort. Other than that, low independence ratio indicates that the regional dependence on central financial is still high.
\end{abstract}

Keywords: Local Government, Financial Performance, Local Financial Racio, Regional Autonomy

\section{Pendahuluan}

Hak otonomi yang diberikan kepada pemerintah daerah di Indonesia ditegaskan dalam Undang-undang Nomor 32 Tahun 2004 yang mengatur tentang Pemerintah Daerah dan didukung juga oleh Undang-undang Nomor 33 Tahun 2004 yang mengatur tentang Perimbangan Keuangan Pemerintah Pusat dan Daerah. Dijalankannya kedua perundangundangan di atas membuat pemerintah daerah menjadi tokoh utama untuk melaksanakan kebijakan serta membangun ekonomi yang yang lebih mandiri. Penyelenggaraan tugas-tugas pemerintahan daerah dapat dijalankan dengan sebaik-baiknya jika dalam penyelenggaraan urusan pemerintahan tersedia sumber pendapatan yang mencukupi sesuai dengan undangundang yang berlaku. Sumber-sumber pendapatan ini juga harus dikelola dengan benar. Pengelolaan keuangan daerah dilakukan dengan sistem terintegrasi yang tertuang dalam APBD yang diatur setiap tahun dalam peraturan daerah. Dari sinilah, peran dari data keuangan berperan dalam menentukan sumber penerimaan daerah beserta jenisnya dan juga besarnya pengeluaran yang harus dikeluarkan supaya perencanaan keuangan bisa berjalan secara efektif.

Karakteristik yang menunjukkan suatu daerah mampu berotomi menurut (Halim, 2004) yaitu terletak pada kemampuan keuangan daerahnya. Ini artinya, daerah otonom harus memiliki kekuatan dan kemampuan terbaik untuk menggali sumber keuangannya sendiri, sekaligus berupaya meminimalkan ketergantungan pada bantuan pemerintah pusat. Dalam rangka mengoptimalkan pelaksanaan otonomi, daerah dituntut untuk lebih kreatif serta inovatif dalam merumuskan kebijakan pemerintah khususnya di bidang keuangan. Implikasinya, satuan kerja pengelola pendapatan daerah harus mampu mengoptimalkan Pendapatan Asli Daerahnya untuk membiayai penyelenggaraan pemerintahan dan pembangunan untuk meningkatkan pertumbuhan ekonomi daerah.

Masalah umum yang biasa dihadapi oleh daerah otonom ialah rendahnya penerimaan $\mathrm{PAD}$, tatkala potensi sumber daya alam maupun manusia cukup melimpah dan potensial untuk dikembangkan di lain sisi, begitu juga yang terjadi Kabupaten Sukoharjo. Berdasarkan sasaran 
yang harus dicapai dalam RPJMD Tahun 2016-2021, kemajuan yang dicapai dalam 2017 dan 2018 serta bermacam masalah dan tantangan pokok harus dipecahkan dan dihadapi pada tahun anggaran 2019 sesuai RKPD 2019. Namun, fenomena yang terjadi pada pelaksanaan kegiatan di tahun berjalan memiliki kendala atau hambatan dalam perekonomian pada menurunnya peranan beberapa sektor yang menjadi sumber penerimaan daerah utama seperti pertanian, kehutanan dan perairan. Kemudian juga, berdasarkan Rencana Kerja Pemerintah Daerah (RKPD) tahun 2019, Kabupaten Sukoharjo mempunyai misi untuk mendorong penguatan kemandirian keuangan daerah. Kemandirian keuangan daerah ini harus memperlihatkan bahwa pemerintah daerah sanggup untuk mendanai sendiri aktivitas pemerintahan, pembangunan serta pelayanan kepada masyarakat yang sudah membayar pajak dan retribusi kepada daerah.

Berdasarkan penelitian sebelumnya, Rahmawati, A. (2016) melakukan penelitian dalam bentuk analisis kinerja keuangan dalam jurnal yang berjudul "Analisis Kinerja Keuangan Pemerintah Kabupaten Sukoharjo Tahun Anggaran 2011-2013" menunjukkan bahwa kinerja keuangan Pemerintah Kabupaten Sukoharjo pada masa itu masih belum optimal. Hal ini dapat dilihat dari porsi PAD terhadap total penerimaan daerah masih sangat rendah disertai dengan tingkat ketergantungan pada bantuan pemerintah pusat maupun provinsi masih sangat tinggi. Padahal seperti yang disebutkan sebelumnya, bahwa dalam berotonomi, suatu daerah dituntut untuk mampu menggali sumber keuangannya sendiri sekaligus berupaya untuk mampu meminimalkan ketergantungannya pada bantuan keuangan dari pemerintah pusat.

Mardiasmo (2002) mengatakan bahwa sistem pengukuran kinerja ranah publik ini memiliki tujuan untuk membantu para manajer publik mengevaluasi pencapaian strategi lewat alat pengukuran finansial dan non finansial. Menurut Halim (2007), kinerja keuangan daerah adalah ukuran yang bisa digunakan untuk melihat dan mengidentifikasi kemampuan suatu daerah dalam menyelenggarakan otonomi daerah. Kinerja keuangan pemerintah daerah merupakan keluaran atau hasil dari program atau aktivitas terkait yang akan atau sudah digapai. Maka, dapat ditarik kesimpulan bahwa kinerja keuangan daerah ialah ukuran yang dihasilkan dari suatu program atau aktivitas yang berkaitan dengan anggaran daerah dan dapat juga digunakan untuk melihat kemampuan daerah dalam rangka penyelenggaraan otonomi daerah.

Oleh karena masalah pokok yang disebutkan di atas dan disertai dengan penelitian pendahuluan, analisis terhadap kinerja keuangan Pemerintah Daerah Kabupaten Sukoharjo diperlukan kembali untuk menghasilkan informasi penting terutama dalam membuat kebijakan dalam pengelolaan keuangan daerah dan menilai kemampuan pemerintah daerah dalam menyelenggarakan otonomi daerah pada saat ini. Pengukuran kinerja keuangan dapat dilakukan dengan menganalisis APBD menggunakan rasio-rasio komponen APBD untuk mengetahui gambaran secara ringkas dan menyeluruh tentang situasi dan kondisi keuangan daerah pada beberapa kurun waktu terakhir. Dengan demikian, penelitian ini dilakukan bertujuan untuk menganalisis kinerja keuangan daerah Kabupaten Sukoharjo yang ditinjau dari perspektif otonomi daerah.

\section{Metode Penelitian}

Penelitian ini merupakan jenis penelitian deksriptif kuantitatif yang digunakan untuk menganalisis kinerja keuangan Kabupaten Sukoharjo. Sumber data berasal dari data sekunder, yang sebagian diperoleh dari Badan Keuangan Daerah (BKD) Kabupaten Sukoharjo. Data-data yang digunakan meliputi Laporan realisasi anggaran Kabupaten Sukoharjo tahun 2015-2019, data PDRB Provinsi Jawa Tengah dan Kabupaten Sukoharjo tahun 2015-2019, data jumlah penduduk Provinsi Jawa Tengah dan kabupaten Sukoharjo 
tahun 2015-2019 disertai dengan data pendukung lainnya. Data tersebut ini dikumpulkan dengan teknik pengumpulan data time series. Sedangkan teknik analisis data yang digunakan yakni analisis rasio keuangan. Fokus penelitian terdiri dari 2 (dua) tujuan analisis kinerja keuangan, pertama, untuk mengetahui tingkat kemampuan daerah dalam menggali, mengelola dan menggunakan sumber daya keuangannya dalam menjalankan otonomi daerah yang menggunakan rasio analisis keuangan, meliputi Rasio Derajat Desentralisasi Fiskal (DDF), Derajat Otonomi Fiskal (DOF), kebutuhan fiskal, kapasitas fiskal, upaya/ posisi fiskal dan efektifitas PAD. Kedua, untuk mengetahui tingkat ketergantungan daerah pada bantuan transfer dari pemerintah pusat, menggunakan rasio kemandirian.

\section{Derajat Desentralisasi Fiskal (DDF)}

Rasio ini menggambarkan tingkat atau derajat kontribusi Pendapatan Asli Daerah (PAD) terhadap Total Penerimaan Daerah. DDF dapat dihitung dengan rumus:

$$
\text { DDF }=\frac{\text { Pendapatan Asli Daerah }}{\text { Total Pendapatan Daerah }} \times 100 \%
$$

\section{Derajat Otonomi Fiskal (DOF)}

Raiso ini menggambarkan tingkat kemampuan pemerintah dalam membiayai sendiri kegiatan pemerintahan, pembangunan dan pelayanan pada masyarakat yang telah membayar pajak dan retribusi. DOF dihitung dengan rumus:

$$
\text { DOF }=\frac{\text { pajak }+ \text { retribusi daerah }}{\text { total belanja daerah }} \times 100 \%
$$

\section{Kebutuhan Fiskal (fiscal need)}

Kebutuhan fiskal memperlihatkan besarnya kebutuhan perkapita penduduk apabila total semua pengeluaran didistribusikan secara merata kepada seluruh penduduk di daerah yang berkenaan. Kebutuhan fiskal menggambarkan kebutuhan daerah dalam menjalankan pelayanan publik.

Kebutuhan fiskal daerah dapat dihitung dengan rumus:

$$
\text { SKbF Prov }=\frac{\text { Jumlah pengeluaran Prov/Jumlah Penduduk Provinsi }}{\text { Jumlah Kab/kota }}
$$

$$
K b F K a b=\frac{\text { Jumlah pengeluaran rutin dan pembangunan masing }- \text { masing daerah }}{\text { SKbF Prov }}
$$

\section{Kapasitas Fiskal (fiscal capacity)}

Perhitungan kapasitas fiskal memperlihatkan seberapa besar upaya dari daerah yang diwujudkan dalam Pendapatan Domestik Regional Bruto (PDRB) atas dasar harga berlaku untuk mencukupi semua kebutuhannya (dalam hal ini, total belanja daerah). Kapasitas fiskal menggambarkan tingkat daya tumbuh keuangan daerah yang dihitung melalui perbandingan antara PDRBH kabupaten perkapita dengan kapasitas fiskal provinsi. 
Berikut rumus perhitungan kapasitas fiskal:

SKaF Prov $=\frac{\text { PDRBHB Provinsi /Jumlah Penduduk Provinsi }}{\text { Jumlah Kab/kota }}$

$K a F$ Kab $=\frac{\text { PDRBHB Kabupaten /Jumlah Penduduk Kab }}{\text { SKaF Prov }}$

5. Upaya/Posisi Fiskal

Guna mengetahui bagaimana upaya fiskal/ posisi fiskal suatu daerah, dapat dihitung dengan mencari koefisien elastisitas PAD. Hasilnya dapat diperoleh dengan membandingkan peningkatan PAD dengan peningkatan Produk Domestik Regional Bruto berdasarkan Harga Berlaku (PDRBHB). Semakin elastis PAD, maka struktur $\mathrm{PAD}$ di daerah tersebut dikatakan semakin baik.

Elastisitas $P A D=\frac{\triangle P A D}{\triangle P D R B} \times 100$

6. Rasio Efeektifitas PAD

Rasio ini digunakan untuk mengetahui kemampuan daerah dalam memobilisasi penerimaan PAD sesuai dengan yang ditargetkan dalam APBD.

Rasio efektivitas $=\frac{\text { Realiasi } P A D}{\text { Target } P A D} \times 100$

Secara umum, kategori atas nilai efektifitas PAD adalah sebagai berikut:

Tabel 1

Kategori Tingkat Efektifitas PAD

\begin{tabular}{lc}
\hline \multicolumn{1}{c}{ Kriteria Efektifitas } & Rasio Efektifitas (\%) \\
\hline Tidak efektif & $<100$ \\
Efektif Berimbang & $=100$ \\
Efektif & $>100$ \\
\hline
\end{tabular}

Sumber: Mahsun (2009)

7. Rasio Kemandirian

Rasio ini digunakan untuk mengukur tingkat ketergantungan dan pola hubungan suatu daerah terhadap bantuan pemerintah pusat dan provinsi. Hasil rasio ini dapat diperoleh dengan membandingkan PAD dengan transfer pusat dan provinsi serta pinjaman daerah.

Rasio kemandirian $=\frac{P A D}{\text { Transfer pusat }+ \text { Prov }+ \text { Pinjaman }} \times 100$ 
Berikut disajikan keterangan untuk mengkategorikan pola hubungan dan tingkat keamandirian keuangan suatu daerah:

Tabel 2

Pola Hubungan dan Tingkat kemandirian

\begin{tabular}{lll}
\hline Kemampuan Keuangan & Kemandirian (\%) & $\begin{array}{c}\text { Pola } \\
\text { Hubungan }\end{array}$ \\
\hline Sangat rendah & $0 \%-25 \%$ & Instruktif \\
Rendah & $25 \%-50 \%$ & Konsultatif \\
Sedang & $50 \%-75 \%$ & Parti sipatif \\
Tinggi & $75 \%-100 \%$ & Delegatif \\
\hline
\end{tabular}

Sumber: Halim, 2004

Menurut Hersey dan Blanchard (dalam Halim, 2004), hubungan antara pemerintah pusat dan daerah dikelompokkan ke dalam 4 hubungan situasional yang mencerminkan pelaksanaan otonomi di di daerah tersebut, yakni:

a. Pola hubungan Instruktif, artinya peran pemerintah pusat lebih dominan (daerah tidak mampu melaksanakan otonomi daerah).

b. Pola hubungan Konsultatif, artinya daerah dianggap sedikit lebih mandiri dan mampu melaksanakan otonomi daerah karena berkurangnya campur tangan dari pemerintah pusat.

c. Pola hubungan Partisipatif, artinya tingkat kemandirian suatu daerah mendekati mampu melaksanakan urusan otonomi daerah karena berkurangnya peran pemerintah pusat.

d. Pola hubungan Delegatif, artinya suatu daerah benar-benar mandiri dan mampu melaksanakan otonomi daerah karena tidak adanya campur tangan dari pemerintah pusat.

\section{Hasil dan Pembahasan}

a. Rasio Derajat Desentralisasi Fiskal (DDF)

Tabel 3

Derajat Desentralisasi Fiskal Kabupaten Sukoharjo Tahun 2015-2019

\begin{tabular}{cccc}
\hline Tahun & $\begin{array}{c}\text { Pendapatan Asli } \\
\text { Daerah } \\
(\mathbf{R p})\end{array}$ & $\begin{array}{c}\text { Total Pendapatan } \\
\text { Daerah } \\
\mathbf{( R \mathbf { p } )}\end{array}$ & $\begin{array}{c}\text { DDF } \\
\mathbf{( \% )}\end{array}$ \\
\hline 2015 & 313.947 .492 .011 & 1.784 .106 .364 .462 & 17,60 \\
2016 & 363.163 .428 .162 & 1.931 .896 .575 .824 & 18,80 \\
2017 & 464.567 .409 .857 & 2.055 .571 .033 .667 & 22,60 \\
2018 & 433.485 .481 .219 & 2.055 .517 .964 .074 & 21,09 \\
2019 & 458.742 .223 .869 & 2.143 .687 .569 .516 & 21,40 \\
\multicolumn{3}{c}{ Rerata } & $\mathbf{2 0 , 3 0}$ \\
\hline \multicolumn{3}{c}{ Sumber: Hasil olahan data sekunder } \\
\hline
\end{tabular}


Dapat dilihat dari tabel 3, dari tahun 2015 sampai dengan 2017 kontribusi PAD pada total penerimaan daerah mengalami peningkatan. Kemudian dari tahun 2017 ke 2018 mengalami penurunan, namun meningkat lagi di tahun 2019 menjadi 21,40\%. Jika dirata-rata, rasio DDF dikatakan masih rendah dengan 20,30\% selama lima tahun. Oleh karena itu, dapat dikatakan bahwa secara rata-rata kemampuan Kabupaten Sukoharjo tahun 2015-2019 dalam menggali sumber daya keuangan melalui PAD masih kurang optimal. Ini disebabkan karena kontribusi PAD terhadap total penerimaan daerah masih di bawah 50\%.

\section{b. Rasio Derajat Otonomi Fiskal (DOF)}

Tabel 4

Derajat Otonomi Fiskal Kabupaten Sukoharjo Tahun 2015-2019

\begin{tabular}{ccccc}
\hline Tahun & $\begin{array}{c}\text { Pajak Daerah } \\
(\mathbf{R p})\end{array}$ & $\begin{array}{c}\text { Retribusi Daerah } \\
(\mathbf{R p )}\end{array}$ & $\begin{array}{c}\text { Total Belanja } \\
(\mathbf{R p )}\end{array}$ & $\begin{array}{c}\text { DOF } \\
(\mathbf{\%})\end{array}$ \\
\hline 2015 & 137.043 .704 .396 & 27.714 .083 .536 & 1.519 .776 .477 .018 & 10,84 \\
2016 & 182.010 .505 .527 & 23.447 .334 .859 & 1.650 .404 .440 .343 & 12,45 \\
2017 & 221.901 .158 .399 & 22.340 .480 .906 & 1.581 .523 .010 .006 & 15,44 \\
2018 & 235.894 .522 .749 & 23.045 .710 .072 & 1.740 .840 .296 .519 & 14,87 \\
2019 & 262.419 .139 .461 & $\begin{array}{c}19.063 .457 .759 \\
\text { Rerata }\end{array}$ & 1.776 .147 .006 .513 & 15,85 \\
& & & $\mathbf{1 3 , 8 9}$ \\
\hline
\end{tabular}

Sumber: Hasil olahan data sekunder

Dapat dilihat dari tabel 4, dari tahun 2015 sampai dengan 2017 DOF mengalami peningkatatan. Kemudian dari tahun 2017 ke 2017 mengalami penurunan, tetapi meningkat lagi di tahun 2019 menjadi 15,89\%. Jika dirata-rata, rasio DOF masih rendah dengan 13,80\% dalam waktu lima tahun tersebut. Oleh karena itu, dapat dikatakan bahwa kemampuan Kabupaten Sukoharjo tahun 2015-2019 dalam mendanai sendiri kegiatan penyelenggaraan pemerintahan, pembangunan dan pelayanan kepada masyarakat yang diukur dengan rasio Derajat Otonomi Daerah dikatakan masih kurang karena secara rata-rata Rasio Derajat Otonomi Fiskal masih di bawah 50\%.

\section{c. Kebutuhan Fiskal}

\section{Tabel 5}

Kebutuhan Fiskal (KbF) se-Jawa Tengah dan Kabupaten SukoharjoTahun 2015-2019

\begin{tabular}{ccccccc}
\hline Tahun & $\begin{array}{c}\text { Pengel. Jateng } \\
(\mathbf{R p})\end{array}$ & $\begin{array}{c}\text { Pengel SKH } \\
(\mathbf{R p})\end{array}$ & $\begin{array}{c}\text { Pend. } \\
\text { Jateng }\end{array}$ & $\begin{array}{c}\text { Pend. } \\
\text { SKH }\end{array}$ & $\begin{array}{c}\text { SKbF } \\
\text { Jateng }\end{array}$ & $\begin{array}{c}\text { KbF } \\
\text { SKH }\end{array}$ \\
\hline 2015 & 17.337 .686 .210 .000 & 1.519 .776 .477 .018 & 33.774 .141 & 864.207 & $14.844,57$ & 108,47 \\
2016 & 20.050 .497 .701 .000 & 1.650 .404 .440 .343 & 34.019 .095 & 871.397 & $16.839,70$ & 112,47 \\
2017 & 24.349 .750 .271 .000 & 1.581 .523 .010 .006 & 34.257 .865 & 878.374 & $20.307,95$ & 88,66 \\
2018 & 26.231 .235 .039 .000 & 1.740 .840 .296 .519 & 34.490 .835 & 885.205 & $21.729,36$ & 90,50 \\
2019 & 26.632 .341 .000 .000 & $\begin{array}{l}1.776 .147 .006 .513 \\
\text { Rerata }\end{array}$ & 34.718 .204 & 891.912 & $21.933,61$ & 90,79 \\
& & & & $\mathbf{1 9 . 1 3 1 , 1 4}$ & $\mathbf{9 8 , 1 8}$ \\
\hline
\end{tabular}

Sumber: Hasil olahan data sekunder

Tabel 5 menunjukkan bahwa rata-rata kebutuhan fiskal standar se-Provinsi Jawa Tengah tahun 2015-2019 adalah sebesar Rp 19.131,14. Sedangkan untuk rata-rata kebutuhan fiskal Kabupaten Sukoharjo tahun 2015-2019 adalah sebesar 98,18. Ini menunjukkan bahwa 
Indeks Pelayanan Publik Perkapita (IPPP) Kabupaten Sukoharjo dalam lima tahun ini adalah sebesar 98,19.

\section{d. Kapasitas Fiskal}

Tabel 6

Kapasitas Fiskal (KaF) se-Jawa Tengah dan Kabupaten Sukoharjo Tahun 2015-2019

\begin{tabular}{ccccccc}
\hline Tahun & PDRB HB Jateng & $\begin{array}{c}\text { PDRB HB } \\
\text { SKH }\end{array}$ & $\begin{array}{c}\text { Pend. } \\
\text { Jateng }\end{array}$ & $\begin{array}{c}\text { Pend. } \\
\text { SKH }\end{array}$ & $\begin{array}{c}\text { SKbF } \\
\text { Jateng }\end{array}$ & $\begin{array}{c}\text { KbF } \\
\text { SKH }\end{array}$ \\
\hline 2015 & 1.010 .986 .640 .000 & 26.700 .720 .000 & 33.774 .141 & 864.207 & $855.249,95$ & 36,13 \\
2016 & 1.087 .316 .680 .000 & 29.130 .310 .000 & 34.019 .095 & 871.397 & $913.198,63$ & 36,61 \\
2017 & 1.172 .794 .520 .000 & 31.621 .410 .000 & 34.257 .865 & 878.374 & $978.123,27$ & 36,81 \\
2018 & 1.268 .454 .780 .000 & 34.194 .630 .000 & 34.490 .835 & 885.205 & $1.050 .759,29$ & 36,49 \\
2019 & 1.362 .457 .380 .000 & $\begin{array}{l}36.927 .460 .000 \\
\text { Rerata }\end{array}$ & 34.718 .204 & 891.912 & $1.121 .237,54$ & 36,93 \\
& & & & $\mathbf{9 8 3 . 7 1 3 , 7 4}$ & $\mathbf{3 6 , 5 9}$ \\
\hline
\end{tabular}

Sumber: Hasil olahan data sekunder

Tabel 6 menunjukkan bahwa kapasitas fiskal standar se Provinsi Jawa Tengah ialah Rp 983.713,74. Sedangkan kapasitas fiskal Kabupaten Sukoharjo ialah sebesar 36,59. Apabila dibandingkan, Kabupaten Sukoharjo memiliki kapasitas lebih kecil daripada kebutuhan fiskalnya $(98,19: 36,59)$. Selisih kurang atau celah fiskal inilah yang nantinya akan ditutup melalui mekanisme transfer dari pemerintah pusat. Dengan demikian, berdasarkan kapasitas fiskalnya, Kabupaten Sukoharjo belum mampu untuk membiayai kebutuhan fiskal daerahnya sendiri. Ini artinya potensi daerah untuk menghasilkan PAD belum dikatakan bagus.

e. Upaya/ Posisi Fiskal

Tabel 7

Pertumbuhan PAD dan PDRB Kabupaten Sukoharjo Tahun 2015-2019

\begin{tabular}{cccc}
\hline \multirow{2}{*}{ Tahun } & \multicolumn{2}{c}{ Pertumbuhan (\%) } & Koefisien \\
\cline { 2 - 3 } & PAD & PDRB & - \\
& Elastisitas \\
\hline 2015 & - & - & 2,37 \\
2016 & 13,55 & 5,72 & 3,79 \\
2017 & 21,82 & 5,76 & 1,24 \\
2018 & 7,17 & 5,79 & 0,93 \\
2019 & 5,51 & 5,92 & \\
\hline \multicolumn{4}{c}{ Sumber: Hasil olahan data sekunder }
\end{tabular}

Tabel 7 menunjukkan bahwa rata-rata laju pertumbuhan PDRB relatif berpengaruh kecil terhadap pertumbuhan PAD dalam lima tahun ini. Pada tahun 2019 pertumbuhan PAD justru lebih kecil dari pertumbuhan PDRB dengan elastisitas 0,93\% (inelastis) atau dapat dikatakan bahwa apabila PDRB naik sebesar 1\%, maka hanya akan menaikkan PAD sebesar 0,93\%. Ini menandakan bahwa upaya perbaikan struktur PAD di Kabupaten Sukoharjo kurang optimal. 


\section{f. Rasio efektifitas PAD}

Tabel 8

Rasio Efektifitas PAD Kabupaten Sukoharjo Tahun 2015-2019

\begin{tabular}{cccccc}
\hline & & \multicolumn{4}{c}{ Bagian PAD (\%) } \\
\cline { 3 - 6 } Tahun & $\begin{array}{c}\text { PAD } \\
\text { (\%) }\end{array}$ & $\begin{array}{c}\text { Pajak } \\
\text { Daerah }\end{array}$ & $\begin{array}{c}\text { Retribusi } \\
\text { Daerah }\end{array}$ & $\begin{array}{c}\text { Pend. } \\
\text { Kekayaan } \\
\text { daerah }\end{array}$ & $\begin{array}{c}\text { Lain- } \\
\text { lain } \\
\text { PAD }\end{array}$ \\
\hline 2015 & 118,48 & 132,78 & 92,77 & 114,87 & 113,00 \\
2016 & 115,33 & 131,89 & 97,04 & 39,15 & 118,34 \\
2017 & 118,78 & 141,25 & 109,09 & 103,96 & 103,11 \\
2018 & 124,43 & 139,34 & 113,92 & 99,94 & 111,38 \\
2019 & 127,54 & 139,88 & 110,70 & 104,03 & 116,17 \\
Rerata & $\mathbf{1 2 0 , 9 1}$ & $\mathbf{1 3 7 , 0 3}$ & $\mathbf{1 0 4 , 7 0}$ & $\mathbf{9 2 , 3 9}$ & $\mathbf{1 1 2 , 4}$ \\
\hline
\end{tabular}

Tabel 8 menunjukkan bahwa pada tahun 2015-2019 Kabupaten Sukoharjo berhasil memobilisasi penerimaan PAD sesuai yang ditargetkan dalam APBD. Bagian PAD dari pajak secara rata-rata dari tahun 2015-2019 memiliki rasio efektifitas penerimaan PAD paling tinggi yakni $137,03 \%$ selama lima tahun ini, sedangkan pada bagian pos Pendapatan Hasil Kekayaan Daerah yang Dipisahkan secara rata-rata dalam kurun tahun lima tahun ini memiliki rasio efektifitas paling rendah dan masuk dalam kategori kurang efektif karena rasio penerimaan PAD dengan target kurang dari 100\%.

Tabel 9

Rasio Kemandirian Kabupaten Sukoharjo Tahun 2015-2019

\begin{tabular}{cccccc}
\hline Tahun & $\begin{array}{c}\text { PAD } \\
\text { (Rp) }\end{array}$ & $\begin{array}{c}\text { Bantuan } \\
\text { pusat+prov+pinj } \\
(\mathbf{R p})\end{array}$ & $\begin{array}{c}\text { Rasio } \\
\text { Kemandirian } \\
(\mathbf{\%})\end{array}$ & $\begin{array}{c}\text { Kemampuan } \\
\text { keuangan }\end{array}$ & $\begin{array}{c}\text { Pola } \\
\text { Hubungan }\end{array}$ \\
\hline 2015 & 313.947 .492 .011 & 1.469 .475 .542 .842 & 21,36 & $\begin{array}{c}\text { Sangat } \\
\text { Rendah }\end{array}$ & Instruktif \\
& & & & Sangat & Instruktif \\
2016 & 363.163 .428 .162 & 1.527 .221 .729 .739 & 23,78 & Rendah & \\
& & & & Rendah & Konsultatif \\
2017 & 464.567 .409 .857 & 1.592 .357 .116 .120 & 29,17 & Rendah & Konsultatif \\
2018 & 433.485 .481 .219 & 1.558 .993 .238 .675 & 27,81 & Rendah & Konsultatif \\
2019 & 458.742 .223 .869 & 1.489 .042 .293 .241 & 30,81 & &
\end{tabular}

Sumber: Hasil olahan data sekunder

Tabel 9 menunjukkan bahwa rasio kemandirian pada tahun 2015 ialah sebesar $21,36 \%$, lalu terjadi kenaikan menjadi $23,78 \%$ pada tahun 2016 dan menjadi sebesar $29,17 \%$ pada 2017. Namun, setelah itu terjadi penurunan pada 2018 menjadi 27,18\%, kemudian mengalami kenaikan kembali pada tahun 2019 dengan 30,81\%.

Dari hasil perhitungan, dapat ditarik kesimpulan bahwa kurun waktu lima tahun, kinerja keuangan Kabupaten Sukoharjo apabila dilihat dari rasio kemandirian, secara rata-rata kemampuan keuangannya masih tergolong rendah dengan pola hubungan dari Instruktif menjadi Konsultatif. Meskipun kemampuan ekonomi masih tergolong kurang, namun meningkatnya rasio ini mengindikasikan adanya sebuah peningkatan kemandirian sekaligus 
menurunnya tingkat ketergantungan Kabupaten Sukoharjo pada bantuan pemerintah pusat. Hal ini karena terjadinya perubahan pola hubungan yang sebelumnya Instruktif (sangat bergantung), juga kini menjadi pola hubungan Konsultatif (ketergantungan mulai berkurang).

\section{Simpulan}

Berdasarkan hasil pembahasan dapat ditarik kesimpulan bahwa ditinjau dari perspektif otonomi daerah, kinerja keuangan Kabupaten Sukoharjo pada taun 2015-2019 dikatakan masih kurang optimal. Hal ini ditunjukkan oleh pertama, kurangnya kemampuan dalam menggali pendapatan asli daerah yang ditunjukkan dengan rendahnya Rasio Derajat Desentralisasi Fiskal (DDF) dan Derajat Otonomi Fiskal (DOF), kemudian ketidakmampuan kapasitas fiskal untuk memenuhi kebutuhan fiskalnya, serta rendahnya upaya/ posisi fiskal. Kedua, masih tingginya tingkat ketergantungan pada bantuan keuangan pemerintah pusat yang dibuktikan dengan masih rendahnya rasio kemandirian.

\section{Referensi}

Halim, A. (2004). Manajemen Keuangan Daerah. Yogyakarta: UPP AMP YKPN

Halim, A. (2007). Akuntansi Sektor Publik: Akuntansi Keuangan Daerah. Jakarta: Salemba Empat.

Mahmudi. (2019). Analisis Laporan Keuangan Pemerintah Daerah. Yogyakarta: UPP STIM YKPN.

Mardiasmo. (2002). Otonomi dan Manajemen Keuangan Daerah. Yogyakarta: Penerbit Andi.

Pemerintah Kabupaten Sukoharjo. (2019). Catatan Atas Laporan Keuangan Pemerintah Kabupaten Sukoharjo Tahun Anggaran 2019. Sukoharjo: BKD

Peraturan Pemerintah Nomor 12 Tahun 2019 Tentang Pengelolaan Keuangan Daerah

Rahmayanti, A. (2016). Analisis Kinerja Keuangan Pemerintahan Daerah Kabupaten Sukoharjo Tahun Anggaran 2011-2013. Jurnal EKA CIDA, 1(1), 40-54. e-ISSN 25033689 